\title{
ОСОБЛИВОСТІ СИНДРОМУ ЕМОЦІЙНОГО ВИГОРАННЯ У МЕДИЧНИХ ПРАЦІВНИКІВ
}

\author{
Т. М. Драга, О. П. Мялюк, І. Я. Криницька \\ Комунальна установа «Міська клінічна лікарня № 10» М. Одеса \\ Рівненський державний базовий медичний коледж \\ ДВНЗ «Тернопільський державний медччний університет \\ імені І. Я. Горбачевського МОз Украӥни»
}

У статті розглянуто сучасні теоретичні підходи до синдрому емоційного вигорання як форми професійної деформації медичних працівників. Звернено увагу на фактори, що викликають вигорання та фази розвитку синдрому емоційного вигорання.

\section{FEATURES OF EMOTIONAL BURNOUT SYNDROME IN HEALTH CARE WORKERS}

\author{
T. M. Draga, O. P. Myaluk, I. Ya. Krynytska \\ Municipal institution «City Clinical Hospital No. 10» Odesa \\ Rivne Basic Medical College \\ I. Horbachevsky Ternopil State Medical University
}

\begin{abstract}
The article presents the current theoretical approaches to the syndrome of emotional burnout as a form of professional deformation of health workers. Attention is drawn to the factors that cause burnout and phases of the emotional burnout syndrome.
\end{abstract}

Вступ. Однією з центральних проблем психологічної науки останніми роками стала поширеність порушень психічної адаптації, яка пов'язана зі зростанням вимог до психологічних ресурсів людини, насамперед із соціально-економічною і політичною нестабільністю в країні. У свою чергу, це призвело до масових специфічних соціально-психологічних явищ, до яких належить і емоційне вигорання $[4,9,11]$.

Основна частина. Одним з інтегральних показників оцінки впливу професійного стресу на працівника $\epsilon$ рівень емоційного вигорання. Згідно з сучасними даними під цим терміном розуміють стан фізичного, емоційного та розумового виснаження, що проявляється в професіях соціальної сфери. Синдром емоційного вигорання включає три основні складові: емоційну виснаженість, деперсоналізацію (цинізм) і редукцію професійних досягнень. Під емоційним виснаженням розуміють відчуття емоційної спустошеності та втоми, викликане власною роботою. Деперсоналізація проявляється у цинічному ставленні

() Т. М. Драга, О. П. Мялюк, І. Я. Криницька, 2017 до праці та об'єктів своєї праці. Редукція професійних досягнень - це виникнення у працівників почуття некомпетентності у своїй професійній сфері, усвідомлення неуспіху в ній [3].

Емоційне вигорання як втрата інтересу до актуальної діяльності відома людству з моменту, коли з'явилися можливість її вибору і рефлексія щодо рівня задоволеності нею. Так, відома історія про Римського імператора Діоклетіана, який після 20 років успішного розширення імперії, придушення повстань і окультурення варварів плюнув на все і поїхав у село займатися улюбленою справою - веденням домашнього господарства [12].

Термін «емоційне вигорання» (burnout) запропонував американський психолог Фрейденберг (1974) для характеристики психологічного стану здорових людей, які перебувають в інтенсивній взаємодії 3 іншими людьми в емоційно напруженій атмосфері при виконанні професійних обов'язків $[6,10]$.

Основоположник ідеї вигорання, К. Маслач, визначає це поняття як «синдром фізичного та емоційного 
виснаження, включаючи розвиток негативної самооцінки, негативного ставлення до роботи і втрату розуміння і співчуття стосовно клієнтів». Доктор К. Маслач підкреслює, що вигорання - це не втрата творчого потенціалу, що не реакція на нудьгу, а скоріше «емоційне виснаження, що виникає на тлі стресу, викликаного міжособистісним спілкуванням» $[7,12]$.

Австралійські вчені M. Pierce та G. Molloy (1990) стверджують, що до емоційного вигорання схильний кожен із нас. Вони доводять, що швидкість «згорання» не пов'язана ні з освітою, ні з рівнем інтелекту, ні навіть з оплатою праці. Чутливі й емоційні люди раніше помічають його симптоми, проте інтенсивність процесу не залежить ні від душевної організації, ні від особистої історії. Єдине, що має значення, - ситуація на роботі та ставлення до неї професіонала [2].

За даними В. В. Шевченко та І. П. Моспаненко, синдром емоційного вигорання - це процес поступової втрати емоційної, розумової та фізичної енергії, який проявляється у симптомах емоційного і розумового виснаження, особистісної відстороненості та зниження задоволення при виконанні роботи [6].

У наш час синдром емоційного вигорання внесений до Міжнародного класифікатора хвороб МКХ-10. Йому присвоєно діагностичний статус МКБ-10:273 проблеми, пов'язані з труднощами управління своїм життям [6].

На сьогодні в літературі, присвяченій синдрому вигорання, вказується на значне розширення сфер діяльності, схильних до такої небезпеки. До них належать: вчителі, психологи, педагоги, вихователі дитячих будинків, соціальні працівники, поліцейські та ін. Проведені в різних країнах дослідження свідчать про те, що особливою «групою ризику» $є$ медичні працівники [7].

Сама професійна діяльність середнього медичного персоналу передбачає емоційну насиченість, психофізичне напруження і високий відсоток чинників, що викликають стрес. Вигорання - почасти функціональний стереотип, оскільки дозволяє людині дозувати і економно витрачати енергетичні ресурси. У той же час, можуть наступати його дисфункціональні наслідки, коли вигорання негативно позначається на виконанні професійної діяльності, таким чином, вивчення цих станів $є$ актуальною проблемою [5].

Робочий день медичної сестри - це спілкування з людьми, в основному з хворими, які вимагають постійної турботи і уваги. Стикаючись з негативними емоціями, медсестра мимоволі залучається в них, че- рез що починає і сама відчувати підвищене емоційне напруження. Люди, котрі працюють у сфері «людина людина», через свою професію змушені багато та інтенсивно спілкуватись з іншими людьми, працювати із високою самовіддачею та відповідальністю. Вони починають асоціювати свою працю з призначенням, місією, тому в них стирається межа між роботою і приватним життям, що призводить до ризику виникнення синдрому вигорання [1].

За даними Л. Н. Юр'євої, традиційно фактори, що викликають вигорання, групують у два блоки: особливості професійної діяльності та індивідуальні характеристики самих працівників. До індивідуальних факторів відносять: вік, стать, рівень освіти, сімейний стан, стаж роботи, особистісні особливості (витривалість, локус контролю, стиль опору, самооцінка, нейротизм, екстраверсія). До організаційних факторів -умови праці, робочі перевантаження, тривалість робочого дня, зміст праці, кількість пацієнтів, складність їх проблем, глибина контакту з пацієнтами, участь у прийнятті рішень, зворотний зв'язок.

У роботі медичного працівника виділяють такі джерела стресу: організаційний, ситуаційний загальний та специфічний, особистісний. Організаційний фактор включає відсутність достатньої можливості для кар'єрного росту, численні обов'язкові освітні та практичні моменти, слабкі служби підтримки персоналу. До загального ситуаційного відносять брак знань, необхідність взаємодії з критично налаштованими хворими, наявність різноманіття етичних моментів, відсутність або слабкість служби з надання психологічної підтримки. До специфічного - брак досвіду, тягар важкої роботи, комунікативні проблеми серед персоналу, проблеми у спілкуванні з пацієнтами та членами їх родин, висока смертність серед пацієнтів відділення. Особистісними джерелами стресу є невміння долати труднощі, низький соціально-економічний статус, психічні розлади (зловживання алкоголем, психоактивними речовинами), наявність сімейної чи особистісної кризи, конфлікти з персоналом або пацієнтом, смерть пацієнта, з яким встановилися тісні зв'язки, початок роботи в новому відділенні, відсутність достатньої кількості вільного часу [8].

А. В. Балахонов [7] виділяє три типи факторів у виникненні синдрому емоційного вигорання у медичного персоналу:

1. Соціальний фактор.

2. Особистісний фактор. «Згорають», як правило, професіонали, для яких діяльність значима, свідомо 
обрана, передбачає відоме емоційне ставлення, орієнтацію на інших людей, тобто ті, які реалізують модус служіння. Співчуваюча людина, орієнтована на інших, при недостатньому зв'язку з реальністю, невмінні оцінювати критично несприятливі фактори, низької стійкості до стресорів медичних професій (таких, як біль, страждання, хвороба і смерть) може стати носієм швидко прогресуючого синдрому емоційного вигорання. Але існує і протилежна думка: за Е. Махер, «авторитаризм» і «низький ступінь емпатії» в поєднанні з фанатичною відданістю справі («я все життя мріяв стати медиком») і реакцією на стрес, агресивністю і апатією (зневірою) при неможливості досягти в короткий термін бажаних результатів можуть ініціювати виникнення симптомів «емоційного вигорання».

3. Фактор середовища (місця роботи). Величезне значення має взаємовідношення з колегами в колективі й те, створюється чи ні ситуація «руху рука в руку», активного спільного вирішення професійних завдань в рамках гуманістичного ціннісного підходу. Колектив (нерідко - включаючи адміністрацію) може знижувати мотивацію діяльності своїм загальним негативним або байдужим ставленням до неї. Крім того, умови роботи можуть не сприяти успішному здійсненню професійних завдань: загальна низька матеріально-технічна база, відсутність медикаментів, добові чергування і відсутність повноцінного відпочинку після них.

За В. В. Бойко [4], до складу синдрому емоційного вигорання входять три фази: напруження, резистенція, виснаження. Кожна фаза включає по 4 симптоми.

Фаза «напруження» - нервове (тривожне напруження) є передвісником і «пусковим» механізмом у формуванні емоційного вигорання.

1. Симптом «переживання психотравмуючих обставин» - проявляється в посиленні усвідомлення психотравмуючих чинників професійної діяльності, які важко або не можливо усунути.

2. Симптом «незадоволення собою» - в результаті невдач або нездатності вплинути на психотравмуючі обставини, людина зазвичай відчуває незадоволення собою, обраною професією, посадою. Діє механізм «емоційного перенесення» - енергетика прямує не тільки і не стільки назовні, скільки на себе.

3. Симптом «загнаності в клітку» - коли психотравмуючі обставини дуже тиснуть і усунути їх неможливо, до нас часто приходить відчуття безвихідності. Ми намагаємося щось змінити, ще і ще раз обдумуємо незадовільні аспекти своєї роботи. Це призводить до посилення психічної енергії за рахунок індукції ідеального: працює мислення, діють плани, цілі, сенси.

4. Симптом «тривоги і депресії» - виявляється у зв'язку з професійною діяльністю в особливо складних обставинах, що спонукають до емоційного вигорання як засобу психологічного захисту. Відчуття незадоволеності роботою і собою породжують могутн $є$ енергетичне напруження у формі переживання ситуативної або особистісної тривоги, розчарування в собі, в обраній професії.

Фаза «резистенції» - фактично опір стресу, що зростає, починається з моменту появи тривожного напруження. Людина усвідомлено або несвідомо прагне до психологічного комфорту, намагається знизити тиск зовнішніх обставин за допомогою наявних у ії розпорядженні засобів.

1. Симптом «неадекватного вибіркового емоційного реагування» - ознака вигорання, коли професіонал перестає вловлювати різницю між проявом емоцій і неадекватним вибірковим емоційним реагуванням. У першому випадку йдеться про вироблену з часом корисну навичку підключати до взаємодії з партнерами емоції досить обмеженого реєстру й помірної інтенсивності: легка усмішка, привітний погляд, спокійний тон мовлення, стримані реакції на сильні подразники, лаконічні форми вираження незгоди. Зовсім інша справа, коли професіонал неадекватно «економить» на емоціях, обмежує емоційну віддачу за рахунок вибіркового реагування під час робочих контактів.

2. Симптом «емоційно-моральної дезорієнтації» нерідко у професіонала виникає потреба в самовиправданні, не виявляючи належного емоційного ставлення до суб'єкта, він захищає свою стратегію. Подібні думки свідчать про те, що емоції недостатньо стимулюють етичні відчуття. Адже професійна діяльність, побудована на людському спілкуванні, не знає виключень.

3. Симптом «розширення сфери економії емоції» має місце тоді, коли дана форма захисту здійснюється поза професійною діяльністю (в спілкуванні з рідними, знайомими та друзями). На роботі професіонал настільки втомлюється від контактів, розмов, відповідей на запитання, що не хочеться спілкуватися навіть 3 близькими.

4. Симптом «редукції професійних обов'язків»-у професійній діяльності редукція проявляється у спробах полегшити обов'язки, які вимагають емоційних витрат. 
Фаза «виснаження» - характеризується більшменш вираженим падінням загального енергетичного тонусу й ослабленням нервової системи. Емоційний захист у формі «вигорання» стає невід'ємним атрибутом особистості.

1. Симптом «емоційного дефіциту» - професіонал відчуває, що емоційно він уже не може допомагати суб'єктам своєї діяльності. Не в змозі увійти в їх становище, брати участь у спільній діяльності, співпереживати, відгукуватися на ситуації, що повинні зачіпати, спонукати, підсилювати інтелектуальну, вольову й етичну віддачу.

2. Симптом «емоційної відчуженості»- особистість майже повністю виключає емоції зі сфери професійної діяльності. її майже нічого не хвилює, майже ніщо не викликає емоційного відгуку - ані позитивні обставини, ані негативні. Реагування без відчуттів і емоцій - найяскравіший симптом «вигорання». Він свідчить про професійну деформацію особистості й завдає збитки суб'єкту спілкування.

3. Симптом «особистісної відчуженості, або деперсоналізації» - проявляється у повній або частковій втраті інтересу до людини - суб'єкта професійної діяльності. Об'єКТ обтяжує професіонала своїми проблемами, потребами, неприємна ні його присутність, ні факт його існування.

\section{СПИСОК ЛІТЕРАТУРИ}

1. Батюх О. В. Синдром емоційного вигорання у медичних сестер / О. В. Батюх // Медсестринство. - 2011. № 1. - C. 11-13.

2. Ермакова Е. В. Изучение синдрома эмоционального выгорания как нарушение ценностно-смысловой сферы личности (теоретический аспект) / Е. В. Ермакова // Культурно-историческая психология. - 2010. - № 1. - С. 27-39.

3. Кужель І. Р. Рівень емоційного вигорання як базовий критерій необхідності та змісту психоед'юкативної та психокорекційної роботи з медичним персоналом хоспісу / І. Р. Кужель // Психіатрія. - 2010. - № 1. - С. 34-39.

4. Міщенко М. С. Особливості дослідження синдрому емоційного вигорання за допомогою методики «діагностика рівня емоційного вигорання / М. С. Міщенко, В. В. Бойко // Young Scientist. - 2015. - № 4 (19). - С. 103-105.

5. Сапаргалиева С. А. Синдром эмоционального выгорания у медицинских сестёр хирургического учреждения / С. А. Сапаргалиева, Е. Н. Усова // Бюллетень медицинских Интернет-конференций. - 2014. - Т. 4, № 11. - С. 1141.

6. Шевченко В. В. Синдром емоційного вигорання працівників освіти / В. В. Шевченко, І. П. Моспаненко // Збірник наукових праць. Психологічні науки. - Вип. 2.13(109). C. 252-257.
4. Симптом «психосоматичних і психовегетативних порушень» - проявляється на рівні фізичного і психічного самопочуття. Перехід реакцій з рівня емоцій на рівень психосоматики свідчить про те, що емоційний захист (вигорання) самостійно вже не справляється 3 навантаженнями і енергія емоцій перерозподіляється між іншими підсистемами особистості. У такий спосіб організм рятує себе від руйнівної потужності емоційного вигорання.

Висновки. Необхідно популяризувати знання про синдром професійного вигорання у медичних працівників та його ранні прояви з метою його подальшої корекції для збереження здоров'я медичного персоналу і продовження його професійного довголіття. Емоційне вигорання негативно впливає не лише на самих працівників, на їхню діяльність і самопочуття, але і на тих, хто знаходиться поруч із ними. Щоб медпрацівник не став заручником хворобливого стану пацієнта слід усвідомити, що суттєва роль у боротьбі з хворобою і відповідальність за життя і здоров'я належить насамперед самому пацієнту. Найкращою профілактикою професійного вигорання $є$ адекватне ставлення до роботи і відведення їй належного місця у житті.

7. Эмоциональное выгорание у медицинских работников как предпосылка астенизации и психосоматической патологии / А. В. Балахонов, В. Г. Белов, Е. Д. Пятибрат, А. О. Пятибрат // Вестник Санкт-Петербургского университета. Сер. 11. - 2009. - Вып. 3. - С. 57-71.

8. Юрьева Л. Н. Профессиональное выгорание у медицинских работников. - К. : Сфера, 2004. - 271 с.

9. Findik U. Y. Operating Room Nurses' Burnout and Safety Applications / U. Y. Findik / / International Journal of Caring Sciences. - 2015. - Vol. 8, issue 3. - P. 610-618.

10. Freundberger H. J. Staff burnout / H. J. Freundberger // Social Scienes. - 1974. - P. 159-166.

11. Khalatbaria J. Correlation of job stress, job satisfaction, job motivation and burnout and feeling stress / J. Khalatbaria, S. Ghorbanshiroudia, M. Firouzbakhsha // Procedia - Social and Behavioral Sciences. - 2013. - Vol. 84. - P. 860-863.

12. Maslach C. Burnout: A multidimensional perspective / C. Maslach // Professional burnout: Recent developments in the theory and research / Ed. W.B. Shaufeli, C. Maslach and T. Marek. - Washington D.C : Taylor \& Trancis, 1993. P. 19-32. 